\title{
CENTRAL ASIAN ECONOMIC REGION AND THE ROLE OF UZBEKISTAN IN IT
}

\author{
Yusupova Gullola Tuhtamurodova
}

Kokand State Pedagogical Institute Teacher Of The Department “History”, Uzbekistan

\section{ABSTRACT}

The article deals with a wide range of problems related to the study of the history of light industry in the Fergana Valley. The issues of developing targeted integrated programs for solving intersectoral and regional problems of national economy planning are highlighted.

KEYWORDS: - Industry, economic zone, Fergana Valley, cotton, Andijan, Namangan, factories.

\section{INTRODUCTION}

A certain territorial part of the national economy of the USSR is considered an economic geographical zone, these zones differ from each other by their production and by the development of the OHS, in each Republic expanded production is formed. Each district has ensured that the "socialist" production in the country "develops" with its current production. In fact, the economic zoning work, which was carried out from the first years of the establishment of Soviet power, continued even in the post-war years. V.M.According to kostennikov, the transfer of production in the country to a peaceful construction work and the planning of the national economy the entire USSR's national economy was developed in three directions - from sectoral, inter-Republican, economic and administrative. This led to an increase in national income over a certain period of time (one year) under the control of the economic councils established economic rayonlarda.

The reforms carried out in the economic life of the country led to the regional management "the formation of economic zones in the USSR and the Regional Division of labor", as a result of which the deployment of productive forces was carried out according to economic possibilities. In 1957, 104 economic districts were formed in the country. These districts were connected by economic interaction with other existing economic districts in the USSR. The economic zone was formed either in one republic, or by uniting several republics. To the districts called the great economic district, it was possible to include the economic districts of the 
CURRENT RESEARCH JOURNAL OF HISTORY 2(12): 42-46, December

2021

DOI: https://doi.org/10.37547/history-crjh-02-12-08

ISSN 2767-472X

(C2021 Master Journals

\section{Crossref doi) 8 Google}

Accepted 26 th December, 2021 \& Published $31^{\text {th }}$ December, 2021

Caucasusorti, the Baltic, Central Asia, which united several republics. They were also called the "great economic district" because of the unification of several republics. This economic rayon was established and people's economic councils were established. Among these districts there is also a large Central Asian economic District, which included the Uzbek SSR, the Kyrgyz SSR, the Tajik SSR, the Armenian SSR. The work on the management of the economy of the Greater Central Asian regions was supervised by the planning and Coordination Council of the Greater Central Asian economic zone, which was established on the basis of the decision of the Central Committee of the CPSU MQ and the USSR Council of Ministers on 26 April 1961.

The main directions of specialization of the production of the republics entering the Greater Central Asian Economic Zone in the all-union labor distribution are the products grown by the modern agriculture - to develop cotton, cocoon, Spruce, leather, wool, lobe crops stem, sugar beet, fruit, grape cultivation and increase the leading role of these industries in the all-union production, the development of industries such as the production of aluminum, magnesium, copper, zinc, lead, electrochemistry, the development of the production of nitrogen mineral fertilizers, plastics and resins, synthetic fibers and gauze, synthetic rubber; upgrading the energy, gas and oil industry with water and fuel, and bunda not only covered the needs of the economic zone, but also met the needs of Kazakhstan and the RSFSR, especially the Ural; machinery and metal processing (production of machinery and equipment for the cotton and cotton cleaning industry, irrigation and textile industry).

The Greater Central Asian economic zone gave 90 percent of cotton, among them the first of the Uzbek SSR, the second of the Turkmen SSR, the third of the Tajik SSR. In the Rayon, 40 percent of the industrial products were made up of cotton cleaning, oil and oil, an industry that produces yarn fabrics. In the supply of construction materials, too, stood in previous places. The Greater Central Asian economic zone is the second largest in the energy sector after eastern Siberia.

Uzbekistan differs from other republics in terms of land area and population. Among them, the regions entering the Fergana economic zone and The Tashkent economic zone are the densely populated areas.

At the enterprises of the national economy of the Uzbekistan SSR, the activity of public offices was established, which was initially established in 1959 in several enterprises under the auspices of the Sverdlovsk people's Economic Council. Technical information was also compiled into public records. Since 1961 year, such bills were formed in other national economic councils of the country. In 1961, 13 public design and technology companies were established at the enterprises owned by the Council of the people's economy of the USSR. In accordance with the decision of the Council of the people's economy of the Uzbekistan SSR and the Soviet of trade union Soyuzs of Uzbekistan in 1961, 17 janvar rationalizators established public offices at enterprises during the Republican estofetas named after the CPSU XXII s'ezdi. As a result, more than a hundredekseks brigades engaged in the introduction of new techniques and implementation of organizational technical measures at enterprises owned by the National Council of the USSR of Uzbekistan, as well as more than five hundredekseks brigades of inventors and rationalizers were also formed .

These brigades were joined by workers of various professions, Masters, technologists, heads of departments, tskh and departments of the enterprise. In accordance with the decision of 
CURRENT RESEARCH JOURNAL OF HISTORY 2(12): 42-46, December

2021

DOI: https://doi.org/10.37547/history-crjh-02-12-08

ISSN 2767-472X

(C2021 Master Journals

Crossref doi

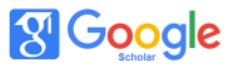

Accepted $26^{\text {th }}$ December, 2021 \& Published 31 th December, 2021

the Council of the people's economy of the Uzbekistan SSR and the trade union Soyuz Soviet of Uzbekistan in 196117 janvar, the Republican estafet of rationalizers named after the CPSU XXII s'ezdi began to form such public brigades. As a result, 17 public Brigades, which are 201 members of mining and metallurgical enterprises, 36 brigades, 138 members of the chemical industry, 10 brigades, 86 members of the energy industry, 39 brigades, 294 members of the mechanical engineering industry, 25 brigades, 143 members of the textile and agricultural industry, 10 brigades, 75 members of the Light Industry, 9 brigades, 31 members

According to the specialization of the Uzbek SSR, initially 4 economic administrative districts Tashkent, Fergana, Samarkand and Karakalpakstan were divided into economic administrative districts . In the post-war years, more than 150 industrial enterprises were put into operation in the Republic. All enterprises of the machine-building industry were seriously repaired or replaced technically. The first plant of the black metallurgy of Uzbekistan - Bekabad metallurgical plant-has been launched. The construction of almalyk copper melting combinat began, Chirchik chemical combinat, Kokand and Samarkand superphosphate plant, Fergana and Andijan ore plants were built, Fergana and Andijan, Yangiyul ore plants were commissioned for use. In the coal industry, new miners have launched powerful reserves for the open extraction of coal in Ohangaron. The construction of the Sharg'un coal field in the surkhandarya region has been accelerated. New oil enterprises were built in the oil industry. Underground oil pipelines and gas pipelines began to work. The largest Farkhod in the USSR was built and completed the hydroelectric power plant. 2 whitewash, 2 v a 3-Bozsuv, two Shahrichon, two Bozs Gras were launched. As a result of the construction of industrial enterprises, the interests of the Republic were tied to the interests of the country, it began to demand the establishment of industries serving the interests of the general public.

In 1960, the Republic was divided into 6 economic districts. They consisted of Tashkent, Fergana, Samarkand, Karshi, Bukhara-Kyzylkum (which included Bukhara and the newly formed Navoi region), lower Amudarya and Surkhandarya economic regions . In 1960 year, the Republic in terms of population was ranked first among the four republics in the Central Asian economic zone, while the RSFSR, Ukraine, ranked fourth afterististan, among the Allied Republics. In the years of analysis, Karakalpakstan ASSR entered the structure of the Republic of Uzbekistan, its population is 451.1 thousand people and territory 159.2 thousand sq. km.ni established. The remaining regions of the Uzbek SSR are divided into to'qqizta region: Tashkent, Fergana, Andijan, Namangan, Samarkand, Bukhara, Kashkadarya, Surkhandarya and Khorezm.

Uzbekistan was a republic whose natural conditions were diverse and convenient mainly for the development of various branches of the national economy, and it had a special place with its vast valleys, scorching sand deserts, mountains, underground and other natural resources. The territory of Uzbekistan is the Middle Land of Central Asia, surrounded by army Republics. Uzbekistan borders on the North and North - West with the Kazakh SSR, in the Eastwith the Kyrgyz SSR and the Tajik SSR, in the south and south-west with the Turkmen SSR, and only in the south a small territory borders on the state border of Afghanistan.

The natural conditions of the Republic are very diverse, along with very fertile valleys, the insidious part of the territory of the Republic was formed by Plains consisting of a very large desert 
CURRENT RESEARCH JOURNAL OF HISTORY 2(12): 42-46, December

2021

DOI: https://doi.org/10.37547/history-crjh-02-12-08

ISSN 2767-472X

(C2021 Master Journals

Crossref doi

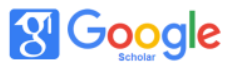

Accepted 26 $6^{\text {th }}$ December, 2021 \& Published 31 th December, 2021

and semi-desert, which were flooded without water. The North-East and east of Uzbekistan are surrounded by extremely large mountain formations, these mountain formations are the regions of the Tajik SSR and the Kyrgyz SSR, and the rivers flowing through the mountains provide water to the fertile lands in the valleys of the cotton and other crops of the Uzbek SSR with numerous irrigation channels. River valleys formed highly developed irrigated peasant oases, the majority of the population of the Republic lived in these oases. Cities and villages, factories and most of the factories are also located in these oases.

\section{REFERENCES}

1. Костенников В.М. Развитие экономических районов СССР. (Перспективы и проблемы). Пособие для учителей. - Москва. Провещение, 1977. -С.10.

2. Досумов Р.Я. Перестройка управления промышленным производством в новых условиях хозяйствования... - С. 24.

3. Зокиров Ш.И. Ўзбекистон халқ хўжалиги ва унинг бутуниттифоқ мехнат тақсимотида тутган ўрни. - Тошкент. “Қизил Ўзбекистон”, “Правда Востока”, "Ўзбекистони Сурх" бирлашган нашриёти, 1960. - 5 бет.

4. Ўз МА. Р-2303-фонд, рўйхат -2 , йиғма жилд -6, 11-14 варақлар.

5. Рудин А. Ўрта Осиё йирик иқтисодий райони // Қизил Ўзбекистон. 1962 йил 13 апрель.

6. Развитие и размещение производительных сил экономических районов СССР. -Москва. Наука, 1967. C.97.
7. Левенсон Л.И. Техникада жамоатчилик. (Ўзбекистон ССР Халқ хўжалиги кенгашига қарашли корхоналардаги жамоатчилик бюроларининг иш тажрибаларидан). Ўзбекистон ССР Давлат нашриёти, 1962. -5 бет.

8. Левенсон Л.И. Техникада жамоатчилик (Ўзбекистон ССР Халқ хўжалиги кенгашига қарашли корхоналардаги жамоатчилик бюроларининг иш тажрибаларидан). Ўзбекистон ССР давлат нашриёти, 1962. - 15 бет.

9. Бедринцев К., Кравец Ф. Фарғона иқтисодий маъмурий райони // Қизил Ўзбекистон. 1957 йил 8 июнь.

10. Совершенствование структуры народного хозяйста Узбекской ССР. Ташкент. Фан, 1987. - С. 72.

11. Управление социалистическим производством. Вопросы теории и практики. - Москва. Экономика, 1978. C. 678-679.

12. Каримов И.А. Ўзбекистон: миллий истиқлол, иқтисод, сиёсат, мафкура. Тошкент: Ўзбекистон, 1996. Т. 1. - Б. 61.

13. СССР экономикасида пахтанинг ахамияти // Қизил Ўзбекистон. 1953 йил 25 ноябрь.

14. Бедринцев К.Н. СССР Халқ хўжалигида Ўзбекистоннинг тутган ўрни. ... - 7 бет.

15. СССР экономикасида пахтанинг ахмияти // Қизил Ўзбекистон. 1953 йил 25 ноябрь

16. Интенсификация развития машиностроительного комплекса Узбекистана.

- Ташкент. Фан, 1988. - С. 34. 
CURRENT RESEARCH JOURNAL OF HISTORY 2(12): 42-46, December

2021

DOI: https://doi.org/10.37547/history-crjh-02-12-08

ISSN 2767-472X

(C)2021 Master Journals

\section{Crossref do) 8 : Google}

Accepted 26 ${ }^{\text {th }}$ December, 2021 \& Published 31 th December, 2021

17. Ў МА. Р-2312-фонд, рўйхат -1 , йиғма жилд - 6, 5- варақ.

18. Развитие и размещение производительных сил экономических районов СССР. -Москва. Наука, 1967. C.247.

19. Искандаров И., Ортиқов А. Мамлакат экономикасида Ўзбекистон саноатининг ўрни ва роли. - Тошкент, 1972. -8 бет.

20. Зиёдуллаев С. Ўзбекистон экономикасининг регионал проблемалари. - Тошкент. Фан, 1987. 33 бет.

21. Бутуниттифоқ қишлоқ хўжалик виставкасида Ўзбекистон // Қизил Ўзбекистон. 1951 йил, 20 апрель.

22. Бедринцев К.Н. СССР Халқ хўжалигида Ўзбекистоннинг тутган ўрни. ... - 9 бет.

23. Зокиров Ш. Ўзбекистон халқ хўжалиги ва унинг бутуниттифоқ мехнат тақсимотида тутган ўрни. - Тошкент. "Қизил Ўзбекистон”, “Правда Востока", "Ўзбекистони Сурх" бирлашган нашриёти, 1960. - 18 бет.

24. Ўз МА. P - 2433-фонд, рўйхат - 3, йиғма жилд - 49, 10- варақ.

25. Ўз МА. P - 2433-фонд, рўйхат - 3, йиғма жилд - 49, 11- варақ.

26. Ўз МА. Р - 2433-фонд, рўйхат - 3, йиғма жилд - 49, 12- варақ.

27. Ўз МА. Р - 2433-фонд, рўйхат - 3, йиғма жилд - 49, 13- варақ. 